Arab Univ. J. Agric. Sci., Ain Shams Univ., Cairo, 14(1), 205-212, 2006

\title{
POTENTIAL FORAGE YIELD OF CANARY GRASS (PHALARIS CANARIENSIS L.) IN RELATION TO BIOFERTILIZER AND SOME MICRONUTRIENTS UNDER RECLAIMED SOIL CONDITIONS
}

[13]

\author{
El-Houssini ${ }^{1}$, A.A.
}

\begin{abstract}
This investigation has been performed in Mariout Research Station, Desert Research Center (D.R.C.) throughout two successive growing seasons of 2002 / 2003 and 2003 / 2004. Canary grass plants were raised under 9 treatments which were the combinations of 3 biofertilizer sources i.e. Azotobacter, Azospirillum and uninoculated control and 3 micronutrients i.e. $2 \% \mathrm{FeSo}_{4}, 1 \% \mathrm{MnSO}_{4}$ and control. The treatments were arranged in split-plot design with three replications.

The important results obtained can be summarized as follows:

1- Maximum values of all growth parameters tested of canary grass plants were obtained when seeds were inoculated with Azotobacter compared to inoculation with Azospirillum or uninoculated control. Fresh and dry forage yields followed the same trend of growth parameters in their response to the different biofertilizer resources.

2- All growth and forage yield traits of canary grass plants were increased when the plants were sprayed with $2 \% \mathrm{FeSo}_{4}$ compared to spraying with $1 \% \mathrm{MnSo}_{4}$ or control treatment.
\end{abstract}

Keywords: Canary grass, Phalaris canariensis, Biofertilizers, Micronutrients

\section{INTRODUCTION}

Ambitious agricultural expansion plans are imperative to meet the demands of the ever increasing population. These plans aim towards the attainment of maximum economical production through the utilization of the full potentials of soil, plant and management. The achievement of such goal under the conditions of high- ly calcareous soils needs thorough investigations of the various factors governing the availability of nutrients and its effects on crop production under these conditions.

Canary grass (Phalaris canariensis L.) is an important winter forage crop successfully used for pasture, hay and silage (El-Houssini, 2000). Generally, forage grasses responded well to nitrogen

1- Range Management Unit, Desert Research Center, Matariya, Cairo, Egypt

(Received September 14, 2005)

(Accepted October 1, 2005) 
fertilization. However, increasing cost of chemical fertilization and their environmental polluted effects have reduced their use considerably. Under such situation, it is imperative to use natural available resources to meet partial nutritive requirements of the crop. Azotobacter and Azospirllum are the most important and well known heterotrophice bacteria which increased the yield of several crops by fixing the atmospheric nitrogen in soil (Sheoran et al 1998).

Azotobacter inoculation significantly increased the green as well as dry matter and crude protein yields of Avena sativa over uninoculated control and Azospirillum inoculated treatments (Sheoran et al 1998). They revealed also that the increase in yield was $13.7,18.4$ and 26.8 percent for green fodder, dry matter and crude protein yields, respectively due to Azotobacter over the control .They added that there was no significant effect of Azospirillum inoculation on fodder and crude protein yields of oat. In a pot experiment conducted by Kundu et al (1997), pearl millet (Pennisetum glaucum) seedlings were root inoculated with 1 of 8 strains of Azospirillum brasilense. They stated that $\mathrm{N}$ fixation was highest with inoculation with the mutant strain Sp 7$6 \mathrm{M}$ and this treatment also produced the highest plant dry weight. Furthermore, inoculating seeds of winter rye (Lolium perenne) and Bromus inermis with selected Azospirillum strains significantly increased $\mathrm{N}$ fixation in the root zone. Inoculation with Azospirillum brasilense or Azospirillum lipoferum increased fresh fodder yield of Lolium perenne by 24.2 and $15.7-25.7 \%$ and that of $B$. inermis by 21.9 and $29.6 \%$, respectively. Also, inoculation increased herbage $\mathrm{N}$ content in both grasses (Maltseva et al 1995).
In the highly calcareous soils, as in Mariout region soils, $\mathrm{CaCO}_{3}$ is considered to be one of the most important factor which affects the availability of nutrient elements (Khalil et al 1978). Also, manganese deficiency problems are common and widespread under the conditions of highly calcareous soils (Wassif $\boldsymbol{e t}$ al 1978). Additionally, several investigations suggested that the availability of manganese is greatly influenced by the $\mathrm{Fe}$ / Mn ratio in the plant (Twyman, 1951). Foliar sprays with a mixture of $2 \% \mathrm{FeSo}_{4}$ $+0.4 \% \mathrm{MnSo}_{4}$ was more effective in increasing the straw yield of sordan plants (Khalil et al 1991). Moreover, Withee and Carlson (1959) pointed out that spraying chlorotic grain sorghum with 3 sprays of $4 \%$ ferrous sulfate was an effective method of improving the yield of grain. In addition, positive response in plant growth, dry matter and iron content were obtained when iron was added to corn plants. Spraying was the efficient method especially with $\mathrm{FeSo}_{4}$, may be due to that spraying protect the iron from rapid oxidation or precipitation by $\mathrm{CaCo}_{3}$ (Abd-Elnaim et al 1974). Also, total plant weight per plant, plant height and yield of maize and its components were significantly increased with microelements i.e. $\mathrm{Zn}, \mathrm{Mn}, \mathrm{Fe}, \mathrm{Cu}, \mathrm{B}$ and $\mathrm{Mo}$ (Glelah et al 1990).

Since little information are available with regard to the fertilizer requirements of canary grass plants at Mariout region, so the aim of this work was to investigate the effect of different sources of biofertilizer and micronutrients on growth and forage yield of canary grass.

\section{MATERIAL AND METHODS}


This study was carried out at Mariout Research Station, Desert Research Center (D.R.C.) throughout two successive growing seasons of 2002/2003 and 2003 / 2004. The objective of this investigation was to study the effect of micronutrients and different bio-fertilizer sources on growth and forage yield of canary grass (Phalaris canariensis L.). Soil at the experimental site is characterized as sandy clay loam texture with $\mathrm{pH}$ of 8.0, EC of $2.78 \mathrm{mmhos} / \mathrm{cm}$ and containing $46.50 \%$ calcium carbonate.

A split-plot design with three replications was used. The main plots devoted to spraying with micronutrients, while the sub plots were occupied with biofertilizer resources.

Each experiment included nine treatments which were the combinations of three micronutrients $\left(2 \% \mathrm{FeSo}_{4}, \quad 4 \%\right.$ $\mathrm{MnSo}_{4}$ and control), three bio-fertilizer resources (Azotobacter, Azospirillum and control). Plot size was $3 \times 3.5 \mathrm{~m}\left(10.5 \mathrm{~m}^{2}\right)$ consisting of 6 ridges each of $60 \mathrm{~cm}$ apart.

Seeds of canary grass (Phalaris canariensis L.) were inoculated with different biofertilizer resources. Inoculation was performed by mixing canary grass seeds with the appropriate amounts of cerealin using Arabic gum as adhesive. The coated seeds were then air dried in the shade for 30 minutes and sown immediately with seeding rate of $15 \mathrm{Kg}$ seeds / fed. on 15 and 18 November in the first and the second season ,respectively. Calcium superphosphate $\left(15.5 \% \mathrm{P}_{2} \mathrm{O}_{5}\right)$ was applied at rate of 120 $\mathrm{Kg} / \mathrm{fed}$. as a basal application during soil preparation.

Harvesting was initiated 70 days after seeding, when the first cut was taken at cutting height of about $5 \mathrm{~cm}$ above the ground surface. Clipping was repeated later by cutting interval of 45 days making three cuts at the first season and two cuts only at the second one.

Ten plants from the interior of the plot border were chosen at random before each cut, which plant height was measured from the top of plant to soil surfaces, No. of tillers / unit area "1/16 $\mathrm{m}^{2}$, flag leaf area and specific leaf weight "S.L.W." were measured. All plants of each plot were harvested to determine fresh and dry forage yields in ton / fed. .

Data of growth and forage yield were statistically analyzed using computer statistical program Co-STAT according to procedures outlined by Gomez and Gomez (1984). Differences between means were compared using L.S.D. value at $5 \%$ level.

\section{RESULTS AND DISCUSSION}

\section{1- Effect of biofertilizer resources}

Data presented in Table (1) show the effect of different bio-fertilizer resources i.e. Azotobacter, Azosbirillum and uninoculated control on some growth traits of canary grass plants grown under Mariout Province conditions.

It is quite clear from the data that all studied growth traits i.e. plant height, No. of tillers, flag leaf area and specific leaf weight were similar in their response to the used biofertilizer resources.

Maximum values of the previous growth traits were obtained when seeds of canary grass were inoculated with Azotobacter compared to that inoculated with Azospirillum or uninoculated control. Such trend towards increasing in all 
Table 1. Effect of biofertilizer resources on some growth traits of canary grass plants at different cuts harvested during 2002 / 2003 and 2003 / 2004 growing seasons

\begin{tabular}{|c|c|c|c|c|c|c|c|c|c|}
\hline \multirow[b]{2}{*}{ Traits } & \multirow{2}{*}{$\begin{array}{c}\text { No. } \\
\text { of } \\
\text { cut }\end{array}$} & \multicolumn{8}{|c|}{ Biofertilizer resources } \\
\hline & & At. & As. & Control & $\begin{array}{c}\text { LSD } \\
5 \%\end{array}$ & At. & As. & Control & $\begin{array}{c}\text { LSD } \\
5 \%\end{array}$ \\
\hline \multirow{4}{*}{$\begin{array}{l}\text { Plant } \\
\text { height } \\
(\mathrm{cm})\end{array}$} & & \multicolumn{4}{|c|}{$2002 / 2003$} & \multicolumn{4}{|c|}{$2003 / 2004$} \\
\hline & $1^{\text {st }}$ & 77 & 76 & 77 & NS & 68 & 62 & 60 & 8.0 \\
\hline & $2^{\text {nd }}$ & 85 & 82 & 84 & NS & 126 & 124 & 125 & NS \\
\hline & $3^{\text {rd }}$ & 49 & 45 & 41 & 7.0 & - & - & - & - \\
\hline \multirow{3}{*}{$\begin{array}{l}\text { No. of } \\
\text { tillers }\end{array}$} & $1^{\mathrm{st}}$ & 68 & 66 & 64 & NS & 64 & 62 & 62 & NS \\
\hline & $2^{\text {nd }}$ & 53 & 53 & 43 & NS & 45 & 43 & 39 & NS \\
\hline & $3^{\text {rd }}$ & 67 & 55 & 52 & 14.0 & - & - & - & - \\
\hline \multirow{3}{*}{$\begin{array}{c}\text { Flag leaf } \\
\text { area }\end{array}$} & $1^{\mathrm{st}}$ & 53.86 & 48.13 & 47.19 & 6.29 & 53.44 & 45.78 & 35.00 & 17.51 \\
\hline & $2^{\text {nd }}$ & 44.98 & 42.83 & 41.32 & 3.30 & 20.59 & 19.58 & 19.61 & NS \\
\hline & $3^{\text {rd }}$ & 10.95 & 9.87 & 8.02 & 2.88 & - & - & - & $\begin{array}{lll}- & - \\
\end{array}$ \\
\hline \multirow{3}{*}{$\begin{array}{l}\text { S.L.W. } \\
\left(\mathrm{mg} / \mathrm{cm}^{2}\right)\end{array}$} & $1^{\mathrm{st}}$ & 3.39 & 3.08 & 3.10 & 0.28 & 3.27 & 3.03 & 2.94 & 0.29 \\
\hline & $2^{\text {nd }}$ & 3.78 & 3.73 & 3.49 & 0.26 & 5.17 & 5.21 & 5.04 & NS \\
\hline & $3^{\text {rd }}$ & 5.66 & 5.65 & 5.60 & NS & - & - & - & - \\
\hline
\end{tabular}

At. $=$ Azotobacter

As. $=$ Azospirillum

S.L.W. = Specific Leaf Weight

studied growth traits by using Azotobacter as a bio-fertilizer - was observed in all cuts harvested in both seasons. However, these increments were significant for plant height in the third and the first cuts of the first and second seasons, respectively. Whereas, No. of tillers in the third cut of the first season only was significantly decreased from 67 for Azotobacter treatment to 52 tiller / unit area for uninoculated one. Also, flag leaf area and specific leaf weight were significantly responded to change bio-fertilizer source. Such effect was noticed in all taken cuts in the first season and in the first cut of the second season for flag leaf area. Moreover, inoculation with Azotobacter significantly increased specific leaf weight. This trend was observed in the first cut of both seasons and in the second cut of the first season.

Thus, it could be inferred that using Azotobacer as biofertilizer for canary grass plants is considered the best biofertilizer treatment for maximizing their most growth traits. Therefore, it seams that a substantial amount of chemical fertilizer could be saved by using biofertilizer which in turn minimizes the production costs and pollution factors which can occur by the excess use of chemical fertilizers. These results are in accordance with those obtained by 
Sheoran et al (1998) on Avena sativa plants.

Arab Univ. J. Agric. Sci., 14(1), 2006 
Table 2. Effect of micronutrients on some growth traits of canary grass plants in different cuts harvested during 2002 / 2003 and 2003 / 2004 growing seasons

\begin{tabular}{|c|c|c|c|c|c|c|c|c|c|}
\hline \multirow[b]{2}{*}{ Trite } & \multirow{2}{*}{$\begin{array}{l}\text { No. } \\
\text { of } \\
\text { cut }\end{array}$} & \multicolumn{6}{|c|}{ Micronutrients } & \multirow[b]{2}{*}{ Control } & \multirow[b]{2}{*}{$\begin{array}{l}\text { LSD } \\
5 \%\end{array}$} \\
\hline & & $\mathrm{FeSO}_{4}$ & $\mathrm{MnSo}_{4}$ & Control & $\begin{array}{c}\text { LSD } \\
5 \%\end{array}$ & $\mathrm{FeSO}_{4}$ & $\mathrm{MnSo}_{4}$ & & \\
\hline \multirow{4}{*}{$\begin{array}{l}\text { Plant height } \\
(\mathrm{cm})\end{array}$} & & \multicolumn{4}{|c|}{$2002 / 2003$} & \multicolumn{4}{|c|}{$2003 / 2004$} \\
\hline & $1^{\mathrm{st}}$ & 76 & 80 & 73 & NS & 61 & 62 & 62 & NS \\
\hline & $2^{\text {nd }}$ & 85 & 83 & 85 & NS & 122 & 130 & 123 & NS \\
\hline & $3^{\text {rd }}$ & 46 & 44 & 44 & NS & 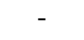 & - & 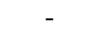 & - \\
\hline \multirow{3}{*}{ No. of tillers } & $1^{\mathrm{st}}$ & 67 & 69 & 63 & NS & 63 & 67 & 58 & NS \\
\hline & $2^{\text {nd }}$ & 59 & 44 & 46 & NS & 46 & 46 & 36 & NS \\
\hline & $3^{\text {rd }}$ & 61 & 56 & 54 & NS & - & - & - & - \\
\hline \multirow{3}{*}{$\begin{array}{l}\text { Flag leaf } \\
\text { area }\left(\mathrm{cm}^{2}\right)\end{array}$} & $1^{\underline{\mathrm{st}}}$ & 48.33 & 51.72 & 47.14 & NS & 67.30 & 40.70 & 30.22 & 36.62 \\
\hline & $2^{\underline{\text { nd }}}$ & 43.53 & 43.96 & 41.65 & NS & 21.70 & 19.76 & 18.31 & NS \\
\hline & $3^{\text {rd }}$ & 10.83 & 9.35 & 7.17 & 3.36 & - & - & - & - \\
\hline \multirow{3}{*}{$\begin{array}{l}\text { S.L.W. } \\
\left(\mathrm{mg} / \mathrm{cm}^{2}\right)\end{array}$} & $1^{\mathrm{st}}$ & 3.17 & 3.32 & 3.06 & NS & 3.32 & 3.18 & 2.74 & NS \\
\hline & $2^{\text {nd }}$ & 3.65 & 3.76 & 3.59 & NS & 5.62 & 4.68 & 5.12 & NS \\
\hline & $3^{\text {rd }}$ & 5.39 & 5.86 & 5.65 & NS & - & - & - & - \\
\hline
\end{tabular}

Table 3. Effect of micronutrients and biofertilizer resources on fresh and dry forage yields of canary grass plants in different cuts harvested during 2002 / 2003 and 2003/2004 seasons

\begin{tabular}{|c|c|c|c|c|c|c|c|c|c|}
\hline \multirow{2}{*}{ Traits } & \multirow{2}{*}{$\begin{array}{l}\text { No. } \\
\text { of } \\
\text { cut }\end{array}$} & \multicolumn{3}{|c|}{ Micronutrionts } & \multirow{2}{*}{$\begin{array}{l}\text { LSD } \\
5 \%\end{array}$} & \multicolumn{3}{|c|}{ Biofertilizers } & \multirow{2}{*}{$\begin{array}{l}\text { LSD } \\
5 \%\end{array}$} \\
\hline & & $\mathrm{FeSO}_{4}$ & $\mathrm{MnSo}_{4}$ & Control & & At. & As. & Control & \\
\hline \multirow{4}{*}{$\begin{array}{l}\text { F.F.Y. } \\
\text { (ton/fed) }\end{array}$} & & \multicolumn{8}{|c|}{$2002 / 2003$} \\
\hline & $1^{\mathrm{st}}$ & 4.400 & 4.089 & 3.533 & NS & 4.467 & 4.022 & 3.533 & 0.912 \\
\hline & $2^{\text {nd }}$ & 4.956 & 4.311 & 4.667 & NS & 4.822 & 4.800 & 4.311 & NS \\
\hline & $3^{\text {rd }}$ & 3.111 & 2.644 & 2.467 & NS & 2.956 & 2.756 & 2.411 & 0.455 \\
\hline \multirow{3}{*}{$\begin{array}{l}\text { D.F.Y. } \\
\text { (ton/fed) }\end{array}$} & $1^{\text {st }}$ & 0.504 & 0.494 & 0.423 & NS & 0.515 & 0.488 & 0.424 & 0.090 \\
\hline & $2^{\text {nd }}$ & 0.646 & 0.581 & 0.606 & NS & 0.689 & 0.647 & 0.507 & 0.172 \\
\hline & $3^{\text {rd }}$ & 0.798 & 0.604 & 0.503 & 0.294 & 0.673 & 0.619 & 0.570 & 0.100 \\
\hline \multirow{4}{*}{$\begin{array}{c}\text { F.F.Y. } \\
\text { (ton/fed) }\end{array}$} & & \multicolumn{8}{|c|}{$2003 / 2004$} \\
\hline & $1^{1^{\mathrm{st}}}$ & 5.589 & 4.933 & 4.100 & 1.341 & 5.956 & 4.911 & 4.156 & 1.332 \\
\hline & $2^{\underline{\underline{n d}}}$ & 14.844 & 13.400 & 13.600 & NS & 14.644 & 13.689 & 13.511 & NS \\
\hline & $3^{\text {rd }}$ & - & - & - & - & - & - & - & - \\
\hline \multirow{3}{*}{$\begin{array}{l}\text { D.F.Y. } \\
\text { (ton/fed) }\end{array}$} & $1^{\mathrm{st}}$ & 0.624 & 0.518 & 0.517 & 0.102 & 0.694 & 0.522 & 0.512 & 0.179 \\
\hline & $2^{\text {nd }}$ & 3.748 & 3.398 & 3.487 & NS & 3.638 & 3.590 & 3.405 & NS \\
\hline & $3^{\text {rd }}$ & - & - & - & - & - & - & - & - \\
\hline
\end{tabular}

F.F.Y. = Fresh Forage Yield D.F.Y. = Dry Forage Yield

Arab Univ. J. Agric. Sci., 14(1), 2006 
As for the effect of different biofertilizer sources on fresh and dry forage yields of canary grass plants, there was a tendency to the increase in the above mentioned traits when seeds of canary grass were inoculated with Azotobacter (Table 3). Such increments in studied forage yield parameters which occurred with using Azotobacter were significant in all cuts except in the second cut of both seasons for fresh forage yield and third cut of the second season for dry forage yield. Such significant effect was noticed between Azotobacter treatment and uninoculated treatment (control). Whereas, there was no significant difference between Azotobacter and Azosbirilum treatments on studied forage yield triats.

These results may be attributed to nitrogen fixation by non-symbiotic bacteria present in the bio-fertilizer cerealin, which produce some growth hormones and consequently increase nutrients uptake by plants (Kotb 1998). These results agreed with those of Sheoran et al (1998) on oat plants. Whereas, Maltseva et al (1995) worked on Lolium perenne and Bromus inermis and found that inoculating with Azospirillum strain significantly increased $\mathrm{N}$ fixation in root zone and increased fodder yield of both grasses.

\section{2- Effect of micronutrients}

It can be observed from data given in Table (2) that studied growth traits of canary grass plants i.e. plant height, No. of tillers / unit area, flag leaf area and specific leaf weight were increased with $\mathrm{FeSo}_{4}$ spray compared to spraying with $\mathrm{MnSo}_{4}$ or control treatment. In most cases, the above mentioned increments in growth traits are below the level of statistical significant. This trend was noticed in most cuts taken in both seasons ,however, flag leaf area was significantly increased by about $51 \%$ in the third cut of the first season and by about $122 \%$ in the first cut of the second one compared with control. These findings are in harmony with the results reported by Khalil et al (1991).

Considering the effect of spraying with micronutrients on fresh and dry forage yields of canary grass plants, it can be observed from data in Table (3) that the greatest values of both fresh and dry forage yields were achieved when canary grass plants were sprayed with $2 \% \mathrm{FeSo}_{4}$ while the lowest values of these traits were obtained with control treatment. Spraying canary grass plants with different micronutrients had a significant effect on dry forage yield. Such significant effect was observed in the third and first cut of first and second seasons, respectively. Whereas, fresh forage yield was significantly responded to micronutrients in the first cut of the second season only. These results agreed with findings of many investigators among whom Withee and Carlson (1959) and Khalil et al (1991).

It is noteworthy to mention that the interaction between the two main factors under the present study i.e. biofertilizer resources and micronutrients seemed to be without effect on all tested growth and forage yield criteria. So, data of the interaction were excluded and implies that each factor acts independently.

\section{REFERENCES}

\author{
Abd-Elnaim, E.M.; Y. Nour Eldien; \\ S.M. Elbasioni and A. Elgala (1974). \\ Effect of iron chelated compounds on \\ corn plants in highly calcareous soils. \\ Agric. Res. Rev. 52: 161-166. \\ El-Houssini, A.A. (2000). Response of \\ canary grass (Phalaris canariensis L.) to
}


kinetin foliar application and cutting management under saline conditions at Wadi Suder. Arab Univ. J. Agric. Sci., Ain Shams Univ., Cairo, 8(1): 197210.

Glelah, A.; A. Omar and M.H. Ibrahim (1990). Response of maize plants to foliar application of microelements. J. Agric. Res. Tanta Univ., 16(3) : 462-470.

Gomez, K.A. and A.A. Gomez (1984). Statistical Procedures for Agricultural Research, $2^{\text {nd }}$ Ed. 680 pp. John Wiley and Sons. New York.

Khalil, M.N.; M.A. Elkadi and S.E. ElDemerdashe (1978). Boron requirements of corn and barley grown under the conditions of highly calcareous soils. Desert Inst. Bull. A.R.E., No. 2: 369376.

Khalil, K.W.; M.S. Barsoum and H.H. Hatem (1991). Response of sordan to foliar and soil application of $\mathrm{Fe}$ and $\mathrm{Mn}$ under conditions of the newly reclaimed highly calcareous soils. Egypt. J. Appl. Sci., 6(7): 17-27.

Kotb, M.Th.A. (1998). Response of wheat to biofertilizer and inorganic $\mathrm{N}$ and $\mathrm{P}$ levels. The Regional Symposium on Agro-Technologies Based on Biological
Nitrogen Fixation for Desert Agriculture. April 14-16, 1998, pp. 291-301 ElArish, North Sinai Governorate, Egypt. Kundu, B.S.; P. Sangwan; P.K. Sharma and A. Nandwal (1997). Response of pearl millet to phytohormones produced by Azospirillum brasilense. Indian Jour. Plant Physi. 2(2): 101-104.

Maltseva, N.N.; V.V. Volkogon and E.V. Nadkernichnaya (1995). Nitrogenfixing associations of azospirilla and some cereal crops. Mikrobiologichnii Zhurnal, 57(1): 24-31. (c.f. Field Crop Abstracts 1996. 49(9): 6127).

Sheoran, R.S.; D.S. Rana and H.R. Sharma (1998). Biofertilizers for sustainable fodder yield and quality of oat (Avena sativa L.). Forage Res., 24(2): 93-95.

Twayman, E.S. (1951). The iron and manganese requirements of plants. New Phytol. 20, 210.

Wassif, M.M.; I.H. El-Bagouri and S.A. Sabet (1978). The effect of manganese fertilization on the growth, Mn and Fe content of corn grown on highly calcareous soils. Desert Inst. Bull., A.R.E. 28, (1) :101-107.

Withee, L.V. and C.W. Carlson (1959). Foliar and soil applications of iron compounds to control iron chlorosis of grain sorghum. Agron. J., 51: 474-476. 


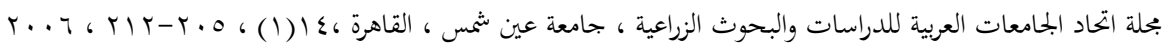

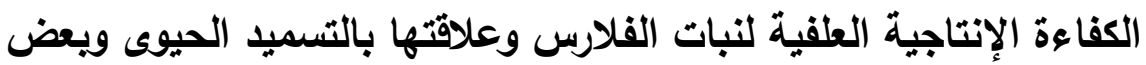
العناصر المغذية الصغرى تحت ظروف الاراضى المستصلحه

[1T]

\author{
أحمد عهد محمد الحسينى' \\ 1- وحدة المراعى - مركز بحوث الصحراء - المطريه - القاهرة
}

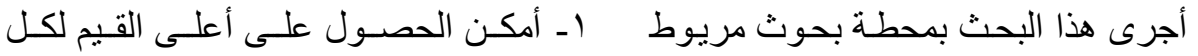

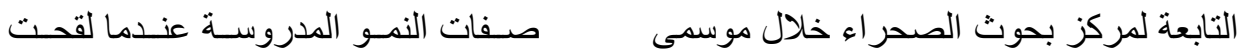

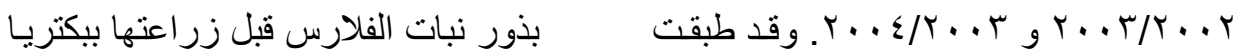

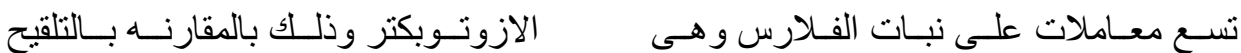

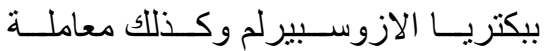
عبارة عن التو افيق بين ثلاث مصادر للتسميد المقارنة . هذا وقد أخذت صفات الحاصل ولت

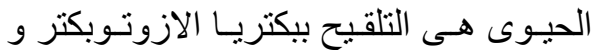
العلفى الغض والجاف نفس الاتجاه .

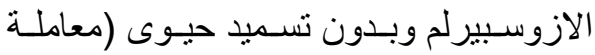

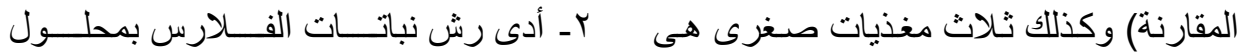

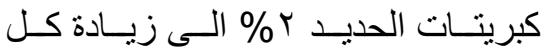

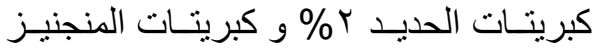
صفات النمو المدروسـه وكذلك صفـات التهات

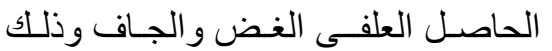

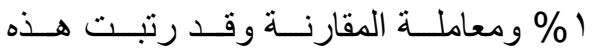
المعاملات فى تصميم قطع منشقه مرة ونة و واحده

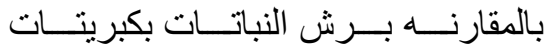
فى ثلاث مكررات . المنجنيز ا \% وكذلك معاملة المقارنه.

ويمكن تلخيص أهم النتائج المتحصل عليها كالآتى : - التمن

تحكيم: أ.د نوكل يونس رزق أ. أد زينب محمود نص نصنار 